\title{
焼結鍛造材の表面欠宿発生に及ぼす製造条件の影響
}

高橋 和彦, 保科 栄介

$$
\text { トヨタ自動車林生技開発部， }
$$

\section{The Effect of Manufacturing Conditions on Surface Defect Production of Powder Forged Material}

Kazuhiko Takahashi and Eisuke Hoshina

Production Engineering Development Div., Toyota Motor Corporation, 1 Toyota-cho, Toyota 471.

Received December 16, 1993

In order to lighten the weight of connecting rods, which are put into service with the surface as forged, mechanical properties, especially fatigue strength of the forged surface should be improved. In powder forged material, surface defects such as decarburized layer, surface roughness, and non-sintered area(NSA) are observed. This NSA, peculiar to this material, plays the most important role in determining the mechanical properties.

In order to develop the optimum strengthening process, the authors focused on this NSA and microscopically observed the microstructure and fractography to quantify the defect, using the ratio of NSA versus the cross sectional area. In addition, the effect of manufacturing conditions on the NSA production mechanism was quantitatively analyzed. As a result, NSA are caused by particle interface oxidation, thought to occur before forging via open-pores.

\section{1 楮 豆}

㜔結銭造法は焼結法の基本的な利点を持ちながら銭 造による維密化で比較的容易に高強度・高用性が得ら れ，また精密に重量管理された圧粉体を热間で閉塞銀造 するため熱間鐉造法に比べて重量精度にすぐれており、 これらの多くの利点が注目され近年自動車用コンロッド を中心に着実に展開が進んでいるいが，一方エンジンの高 出力化及び低撚費化のニーズに応えるため往復運動部の 中でも重量の大半を占めるコンロッドの軽量化を望む声 が高まっている.

鍛造肌で使用されるコンロッドを軽量化するためには
機械的性質として特に黒皮状態での疲学強度を向上する 必要がある. Fig. 1に焼結鎪造法の工程と各行程で発生

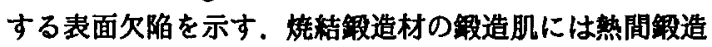
材と同粎脱炭，面䇣れに加え粉末粒界に治った異常組樴 および残留空孔などこの材料特有の欠陥が钼察される。 焼結鉎造材の最適な强化法を開発するため本研究では この材料特有の欠陥に着目し，まず組織及び破面のミク 口覞察を行い欠陥量を定量化しその発生量に及ぼす彆造 条件の影礕を定量的に明らかにしたので報告する。

\section{2 侙方法}




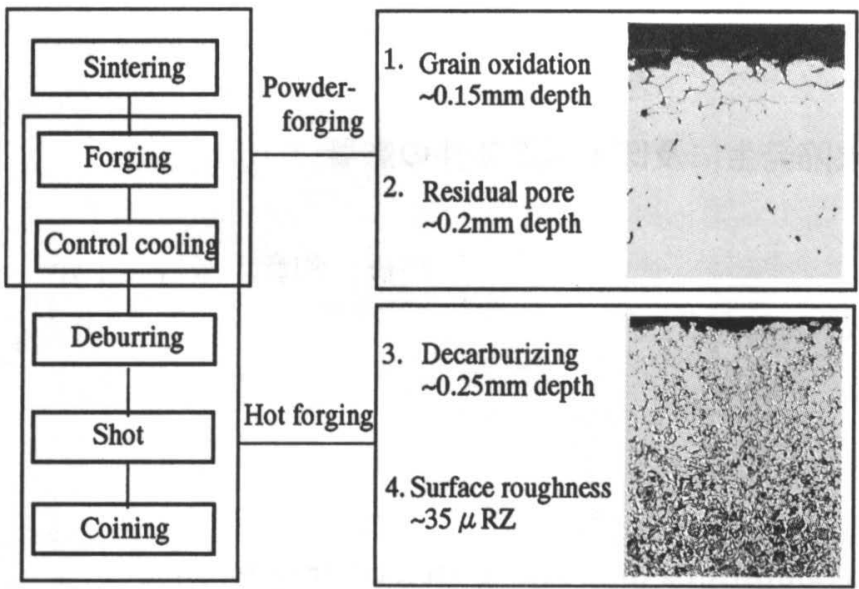

Fig. 1 Powder forging process and it's surface defects.
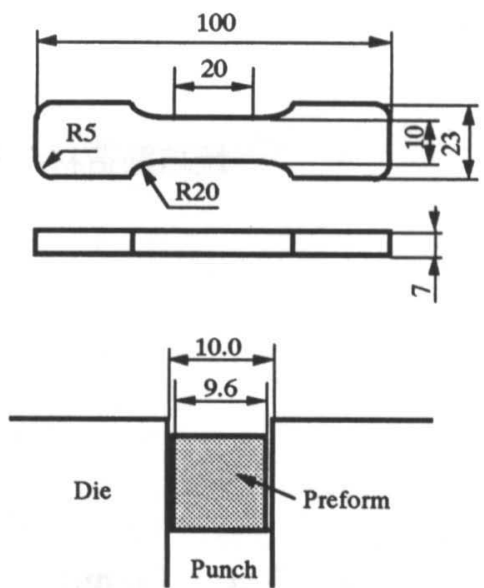

Fig. 2 Dimension of powder forging test sample and schematic diagram of sintered preform and forging die.

2 -(1)供試材

アトマイズ鉄粉（神戸製鋼社製アトメル300M），電解 銅粉（福田金属䇴粉社製CE25），天然黒鉛粉（日本黒鉛 社製ACP1000），ならびに潤滑剤としてステアリン酸亜 鉛（日本油脂社製）を用いて $\mathrm{Fe}-2 \mathrm{wt} \% \mathrm{Cu}-0.6 \mathrm{wt} \% \mathrm{Gr}$ $0.6 \mathrm{w} t \% \mathrm{stZn}$ の組成で V型混粉機で600sec混粉し，200〜 $600 \mathrm{MPa} て ゙$ 圧粉成形した後吸熱型分解ガス中で1423Kにて 600 sec焼結を行い，0.3〜1.1GPaでFig.2に示す形状に鉂造 を行った. なお成形ブリフォームは $98 \mathrm{~g}$ 一定で銭造型との クリアランスが片側で $0.2 \mathrm{~mm}$ の形状とし，コイニングタ イプで般造を行った。鐉造型は水溶性Grで潤滑した。 ま た焼結体を炉から取り出し，鏗造するまでに大気中に露 出する時間は 5 〜 5 secとした.

\section{2 -(2)実験方法}

得られた鍛造体の表面欠陥を覾察するため断面の光学 頭微鏡覞察, 走查電子影徽鏡 (以後SEM) 䘽察, EPMA 分析を行った. また引張試験を行った破断面のSEM锶察 ならびにマイクロオージェ分析を行った．オージェ分析 は日本電子製 JAMP-30を用いて加速電圧10KV, 照射電 流 $3 \times 10^{-7} \mathrm{~A}$ で行った。 またイオンエッチングビームとし ては加速電圧 $3 \mathrm{KV}$ のArビームを用い, エッチング速度は $\mathrm{SiO} 2$ 換算で10 $\mathrm{nm} / 60 \mathrm{sec}$ である.

試料断面の䤒素浱度分析にはEPMAでビーム径30ミ吅り

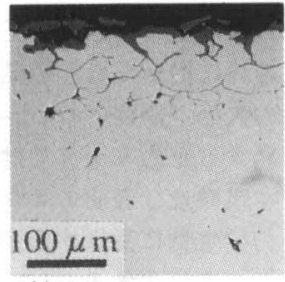

(a) Optical microgaph (b) SEI

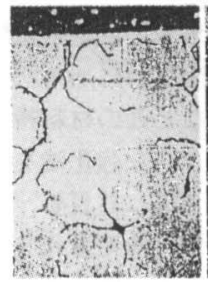

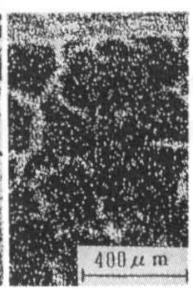

(c) $0-\mathrm{K} a$
Fig.3 Intergranular oxidation in surface area of powderforged steel.
とし表面と平行に $1 \mathrm{~mm}$ 分析し, 各々の深さで平均酸素濃 度を算出した。

焼結プリフォームの酸化速度を測定するため前述の組 成で引張試験片と同一質量の $\phi 30$ の円柱状試験片を200 $600 \mathrm{MPa}$ で両押し成形し, 一度吸熱型ガス㞣囲気中で $1423 \mathrm{~K} 600 \mathrm{sec}$ の予備狫結後重量測定を行い, 再度焼結温 度まで加熱した後大気中に取り出し，5〜25sec保持した 後アルゴンガス中で室温まで冷却後重量測定して大気露 出による重量変化率から酸化速度を求めた.

\section{3結果およひ教丵}

3 -(1) 表面欠陥とその定量化

この材料はFig. 3に示すように光学顕徵鏡で観察する と, 表面から 最大約 $0.15 \mathrm{~mm}$ の深さまで原料粉末粒界に 添った黒い模様が見られ，EPMAの分析結果からこの部 分は酸化していることが確認できる。一方この材料の静 的破断面はFig.4のSEM写真に示すように擬へき開の粒内 破壞の形態をとるが，表面部には原料粉末の形状がその まま残り粉末界面が結合がしなかったことを示す部位

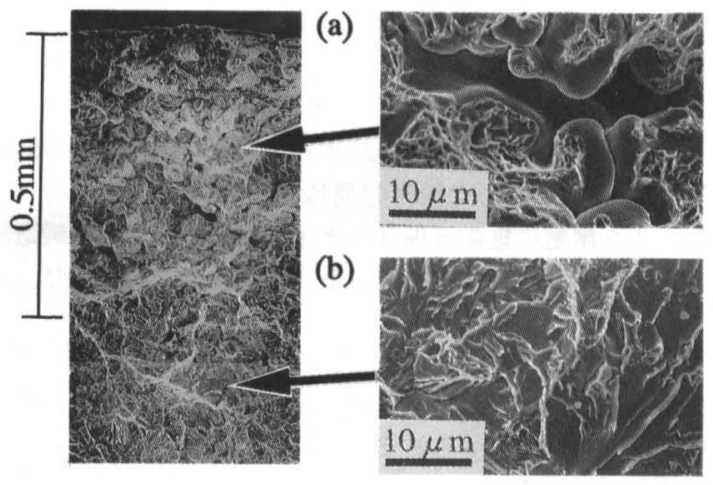

Fig. 4 SEM photograpfs of tensile fracture. (a) Non-sintered area in surface area,(b) quasi-cleavage fracture of innerpart. 
(a)

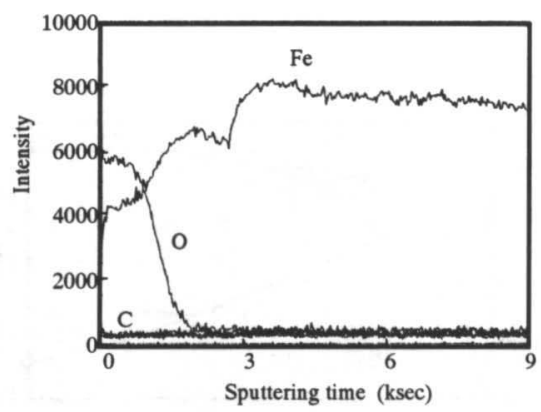

(b)

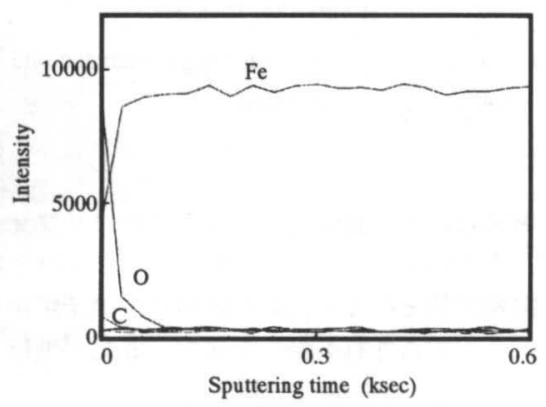

Fig.5 AES in-depth Profile of Fe,O,C. (a) Non-sintered area, (b) quasi-cleavage fracture of innerpart.

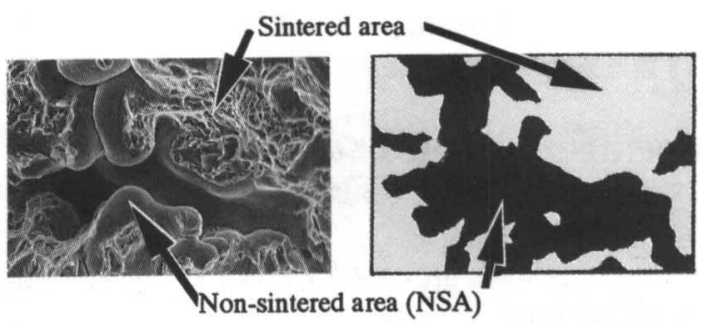

Fig. 6 Measurement of non-sintered area (NSA) ratio.

（以後未焼結部）が混在し，未焼結部は約 $0.5 \mathrm{~mm}$ の深さ まで分布している.

Fig. 5 に静的破断面のマイクロオージェ分析の結果を示 す. 試料内部の擬へき開破壊部位(Fig.5(b))は分析時の污 染と考えられる最表面の酸素しか検出されないのに対 し, 未焼結部(Fig.5(a))は明らかに高い酸素量が検出され る. 前述の粉末粒界に沿った異常組織はこの未燒結部の うち酸化が顕著な部分に相当するものと考えられるっ。 ま た表面付近に䧽察される残留空孔についても引張破面の 未焼結部に含まれるものと考えられる.

そこで本研究ではこの未焼結部に注目し, Fig. 6 に示 したように静的破断面を500倍で撮影したSEM写真（貔 察視野 $250 \mu \mathrm{m} \times 170 \mu \mathrm{m})$ をもとに未焼結部を識別しイ メージアナライザーを用いて未烧結部の面積率を測定し 欠陥量を定量化した. 測定位置および面積率分布の一例

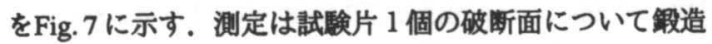
時の上下パンチ面側の表面部 6 ケ所についてパンチ面側 から加圧方向に測定した. 未焼結部の面積率は表面から 内部に入るに従い徐々に低下し約 $0.5 \mathrm{~mm}$ の位置でほぽゼ

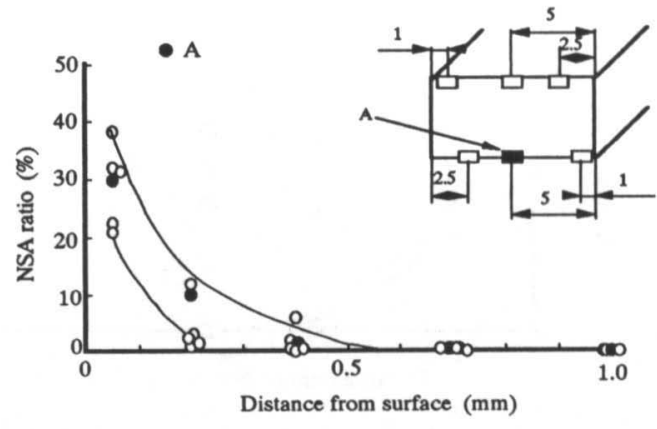

Fig. 7 NSA distribution and measuring spot in a fractured surface.

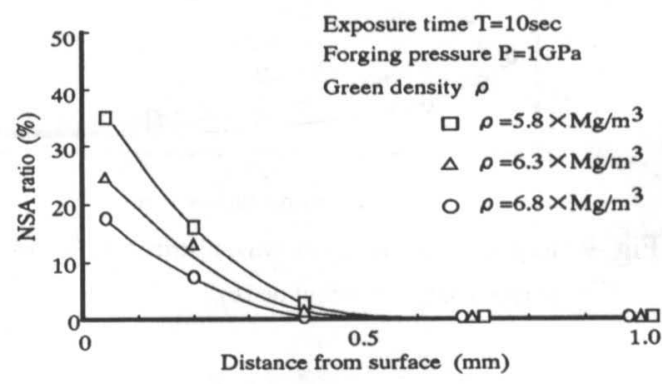

Fig. 8 Green density effect on NSA distribution.

ロとなる．また角稯部に近いほど高く，上下パンチ面側 を比較すると下パンチ側が高い傾向にある．本研究では 以後平均的な欠陥量が観察される下パンチ面側の中央

（Fig. のA部）で試料の欠陥量を調べることにした。

3 -(2)未焼結部の発生量に及ほすす製造条件の影響

未焼結部の発生量に及ほす製造条件の影敏を調査する ため焼結体が大気中に露出する時間，焼結体の密度，鉂 造面圧を変えて，面積率分布に及ほすす影遙を調べた．

Fig. 8 に大気露出時間を $10 \mathrm{sec}$, 鍜造面圧を $1 \mathrm{GPa}$ 一定と し焼結体密度を5.8 $6.8 \mathrm{Mg} / \mathrm{m}^{3}$ まで変化させたときの未焼 結部面積率分布を示す. 焼結体密度が低いほど未焼結部 の面積率は高く若干内部まで深く分布する

Fig. 9 (a) に焼結体密度を $6.3 \mathrm{Mg} / \mathrm{m}^{3}$, 銉造面圧を $1 \mathrm{GPa}$ 一 定とし大気露出時間を $5 \sim 15 \mathrm{sec}$ まで変化させたときの未 焼結部面積率分布を示す. 大気露出時間が長いほど未焼 結部の面積率は高く若干内部まで深く分布する．Fig. 9 (b) は同し試験片用いて破断面と平行に切断した断面を EPMAで酸素分析を行った結果である. 大気露出時間が 長いほど酸化レベルが高く内部まで酸化が進んでいる. また未焼結部が䂓察される深さとほほ同等もしくは若干 深い位置まで内部に比べ高い平均酸素量が検出される.

Fig. 10に大気露出時間を $10 \mathrm{sec}$, 焼結体密度を $6.3 \mathrm{Mg} / \mathrm{m}^{3}$ 一定とし, 錪造面圧を0.3 1.1GPaまで変化させたときの 未焼結部面積率分布を示す. 鎦造面圧が低いほど未焼結 部の面積率は高く若干内部まで深く分布する.

Fig. 11は円柱状の焼結体を用いて烧結温度まで加熱し 
(a)

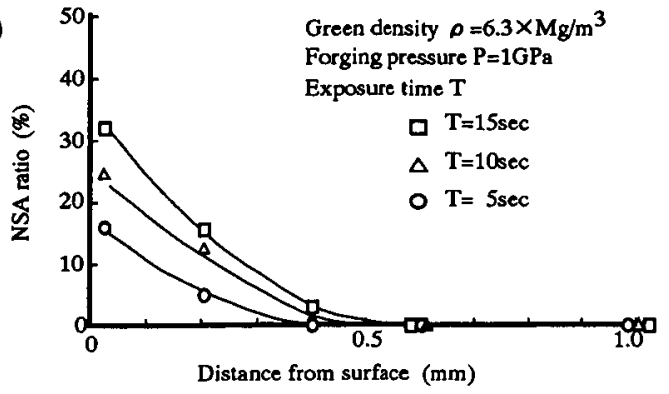

(b)

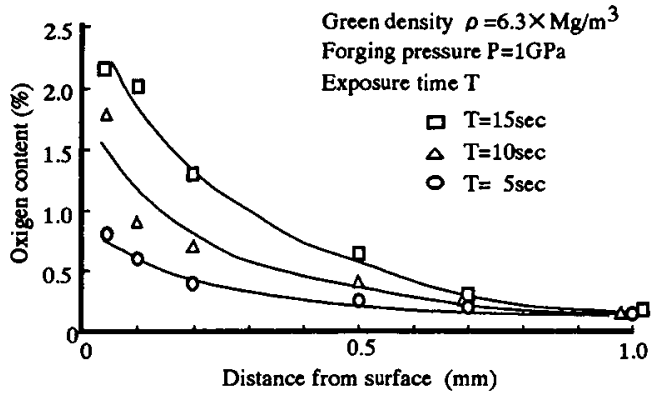

Fig. 9 Exposure time effect on NSA distribution (a) and oxigen content distribution (b).

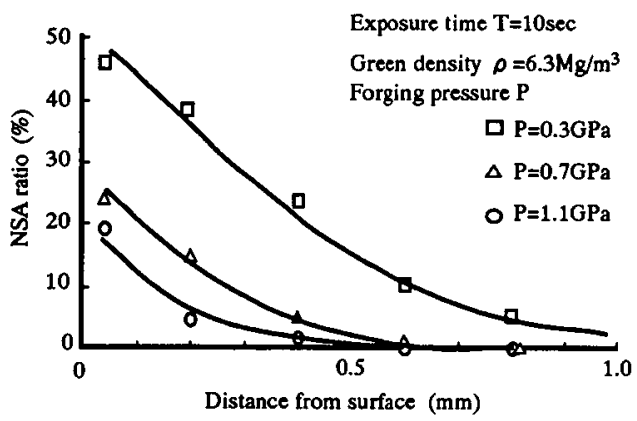

Fig. 10 Forging pressure effect on NSA distribution.

た狫結体の大気路出時間と重量增加率ならびに試料温度 変化を示したものである.試料温度は大気中露出時間と 比例してほほ直楾的に低下し，25secの間に $1423 \mathrm{~K}$ から約 1100Kまで低下する。

一方試料重量は大気路出後の約 $10 \sec の$ 間に急激に増加 し約15secで飽和する。このように試料重量の增加すなわ

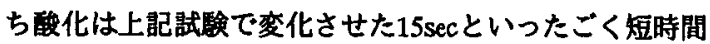
の大気露出により急速に進行することが確認できた。

粟野らは焼結ブリフォームを鍛造する過程で発生する 割れの再圧着現象に関しあらかしめ錐穴を開けたプリ フォームを用い鍜造試験を行い，般造割れは再圧着する 場合があり添加されたCは錐穴の酸化を防ぎ圧着を助け ていると報告しているの。本研究で淕諗している未焼結部 は跟造により機棫的に鹳密化を行っても粉末界面が十分 金属結合しなかった部位で，上記の実䍄結果からこの結 合不良には粉末界面の酸化が重要な役割を果たしている

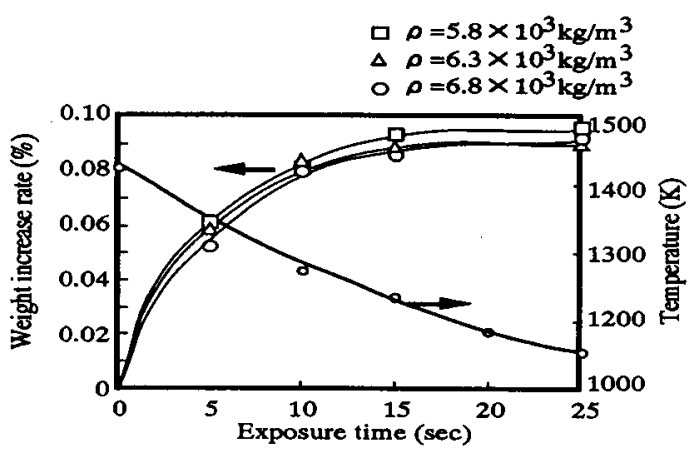

Fig. 11 Exposure time effect on weight increase rate and temperature of specimen.

ものと考えられる．開気孔を有する焼絬ブリフォームは ミクロに見れば前述の錐穴と同様に佊くものと考えら れ，高温に加熱された多れ䁈な焼結体が接結炬から般造 型内に大気中搬送される際に表面から酸化が進行するも のと考えられる。

\section{4 結 吾}

焼結鍤造材の表面欠陥である面荒れ，脱炭，末焼結部 の中でこの材料特有の未娃結部に着目しその発生量に及 ほす製造条件の影辢を定量的に調查し，以下の結果を得 た.

(1)静的破断面のSEM锶察写真から未焼結部を識別し面榬 事を測定することにより未娃結部の発生量, 分布状態 を定量的に把提できた。

(2)未焼結部は表面に近いほど多く覞察され，内部に入る に従い隇少する。

(3)未焼結部の発生量は姥結体の大気露出時間が長い程, また焼結プリフォーム密度および鐉造面圧が低いほど 增加する。

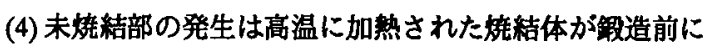
大気中に虂出した際, 表面部の開気孔を介し粉末界面 が酸化することにより般造を行っても十分な焼結が行 われなかったものと教えられる。

最後に本研究を発表するにあたり有益な助言や示唆を 賜わりました東北大学工学部の渡辺能三教授に深く感謝 の意を表します.

\section{文暗}

(1)大西,栍木,永礼,高橋:日本金属学会叝,22 (1983) 537.

(2)程木,永礼,彦坂,岩間,半沢:卜ヨ夕技術,33 (1983) 173.

(3)荒木,佐蕂,高原,落: R\&D/神戸製銅技叝,42 (1992) 24.

(4)M.Weber: SAE Tech Pap Ser, SAE-9101571

(5)H.F.Fishmeister,L.olsson,K.E.Eatsterling: Powder Metall Int , 6 (1974) 30.

（6)䍘野,渡辺，団野,伊東,木村: 粉体およひ粉末冶金, 25 (1987) 229. 